\title{
Structure, composition and diversity of trees within the dry evergreen reserve forest of Kondapalli (Eastern Ghats, southern India)
}

\author{
Pillutla Rama Chandra Prasad ${ }^{1 *} \&$ Jasti Asha Kumari²
}

${ }^{1}$ Lab for Spatial Informatics, International Institute of Information Technology, Gachibowli, Hyderabad, India - 500032

${ }^{2}$ Department of Botany, Maris Stella College, Vijayawada, Andhra Pradesh, 500008, India

* corresponding author (e-mail: rcprasad@iiit.ac.in; ORCID: http://orcid.org/0000-0001-5285-9827)

\begin{abstract}
The dry evergreen forest of Kondapalli (Andhra Pradesh state, India) is declared as a forest reserve, but, despite of this, it is subjected to degradation resulting in loss of biodiversity. Thus, the current study was carried out to investigate the tree diversity of Kondapalli forest. A total of $566 \pm 16$ trees $(\geq 10 \mathrm{~cm})$ representing $46 \pm 8$ species from 40 genera and 21 families were recorded from the 0.36 ha area of Kondapalli forest. Mimosaceae was the most species rich family, while Rutaceae was the most abundant family. Atalantia monophylla was most frequent and abundant species and, with respect to basal area, Melia azedarach and Syzygium cumini were the dominant taxa. The recorded stem density was 1572 stems ha $^{-1}$ and the mean forest basal area was $47.17 \mathrm{~m}^{2} \mathrm{ha}^{-1}$. The results of cluster analysis revealed that Atalantia monophylla, characterised by a high ecological amplitude, had a wide distribution and was associated with species forming different communities. The study showed that Kondapalli forest is characterised by a fairly high species richness, which provides the baseline data on the floristic structure and diversity of this forest for better management and conservation.
\end{abstract}

Key words: dry evergreen forest, degradation, diversity, species richness, ecological amplitude

\section{Introduction}

Currently, tremendous pressure is exerted on natural resources, exploiting them at the maximum limit beyond their regeneration and recover capacity (Pech \& Sunada 2008; Timah et al. 2008). Globally, forest ecosystems are threatened due to various anthropogenic activities connected with overuse of forest resources or area encroachment for agriculture, settlement and economic development (Iftekhar \& Hoque 2005). Depletion and degradation of forests not only results in the loss of valuable goods and services provided by them, but also have an effect on the climate (Prasad et al. 2010). In turn, climate change has a negative feedback on ecosystems by modifying their structure, as well as species composition. A component that is worst affected by the cumulative pressure of anthropogenic and natural factors, is biodiversity. The recent studies on biodiversity revealed the consequences of climate change, such as: sea level rise leading to the loss of bio- diversity due to the submergence of islands and coastal areas (Bellard et al. 2014), rise in temperature resulting in the shifting of species (Donato 2013), replacement of native species by invasive species (Kumari et al. 2010), and transformation of forest types (Prasad et al. 2010), etc.

Some natural ecosystems across the world have been declared as protected and reserve areas, wildlife sanctuaries and national parks. Also, some areas were tagged as "Biodiversity Hotspots", due to their high species richness, diversity, and endemism (Marchese 2015). The main purpose of giving such a status to forest ecosystems is to retain their virgin structure and biodiversity and restore them, if they are in degraded condition, through strict protection against human interference. However, in spite of assigning such a legal status to these ecosystems, their exploitation is in some cases still continued, resulting in the destruction, degradation and loss of biodiversity. An example of such a situation is the Kondapalli Reserve Forest (KRF) of 
Krishna district, Andhra Pradesh state (AP), India. This forest, in the form of a remnant patch, serves as green lungs for the city of Vijayawada in the Krishna district and is under a serious threat resulting from various human interventions (Salghuna et al. 2018). The forest was declared a reserve, with demarcated boundaries, in 1980 under the forest conservation Act. Despite declaring it a reserve area, it is subjected to degradation resulting in the shrinking of forest along the boundaries, as well as within its interior (Anonymous 2001; Prasad et al. 2011). Several changes in land use and land cover occurred in the vicinity of KRF, such as: agricultural development, mining activities, and establishment of settlements and industries. All these changes not only deteriorated the forest, but also affected its biodiversity (Pullaiah \& Sandhya Rani 1999). Salghuna et al. (2018) reported a decrease in the forest cover from 11500 ha (1990) to 10600 ha (2015). In addition, a new threat to the forest comes from the proposal of AP Government to denotify a portion ( $890.43 \mathrm{ha}$ ) of KRF for a new state capital establishment (Anonymous 2017).

Hitherto, some floristic inventories and medicinal plant surveys were conducted in KRF (Venkanna 1990; Reddy et al. 2005, 2010), but no attempt has been made to quantify the floristic structure, species richness and tree diversity patterns. A detailed assessment of tree diversity of the reserve is essential in the context of human interference needed for its conservation. Hence, the objectives of this study were: $(i)$ to investigate the floristic structure, composition and diversity of KRF (ii) to check whether it is apt to compare ecosystems flourishing under dissimilar environmental conditions (iii) to review the diversity patterns of other dry evergreen forests of southern India and assess the status of KRF in relation to those forests, but not to compare their diversity patterns. The study is first of its kind carried out for KRF. The result of this research is expected to provide better insights for formulating and strengthening the conservation measures in KRF and for the sustainability of this reserve in long term perspective.

\section{Materials and methods}

\subsection{Study area}

The Eastern Ghats (EG) of the southern India form one of nine floristic zones of the country that stretches across three states: Tamil Nadu, AP and Orissa. They are discontinuous and divided into the southern and northern EG. KRF (situated between $16^{\circ} 37^{\prime} \mathrm{N}$ and $80^{\circ} 31^{\prime} \mathrm{E}$ latitudes and $16^{\circ} 45^{\prime} \mathrm{N}$ and $80^{\circ} 26^{\prime} \mathrm{E}$ longitudes), with an area of $121 \mathrm{~km}^{2}$, is located on the western side of Vijayawada city and forms a connection between these two parts (Rao \& Pullaiah 2007) (Fig. 1). The study area is characterised by tropical climatic conditions with an average annual temperature of $28.5^{\circ} \mathrm{C}$ and rainfall of $1067 \mathrm{~mm}$ (climate.org). Geologically, the area is dominated by gabbroic and anorthosite rocks with subordinate ultramafic rocks, plagioclase, orthopyroxene and clinopyroxene (Leelanandam 1994).

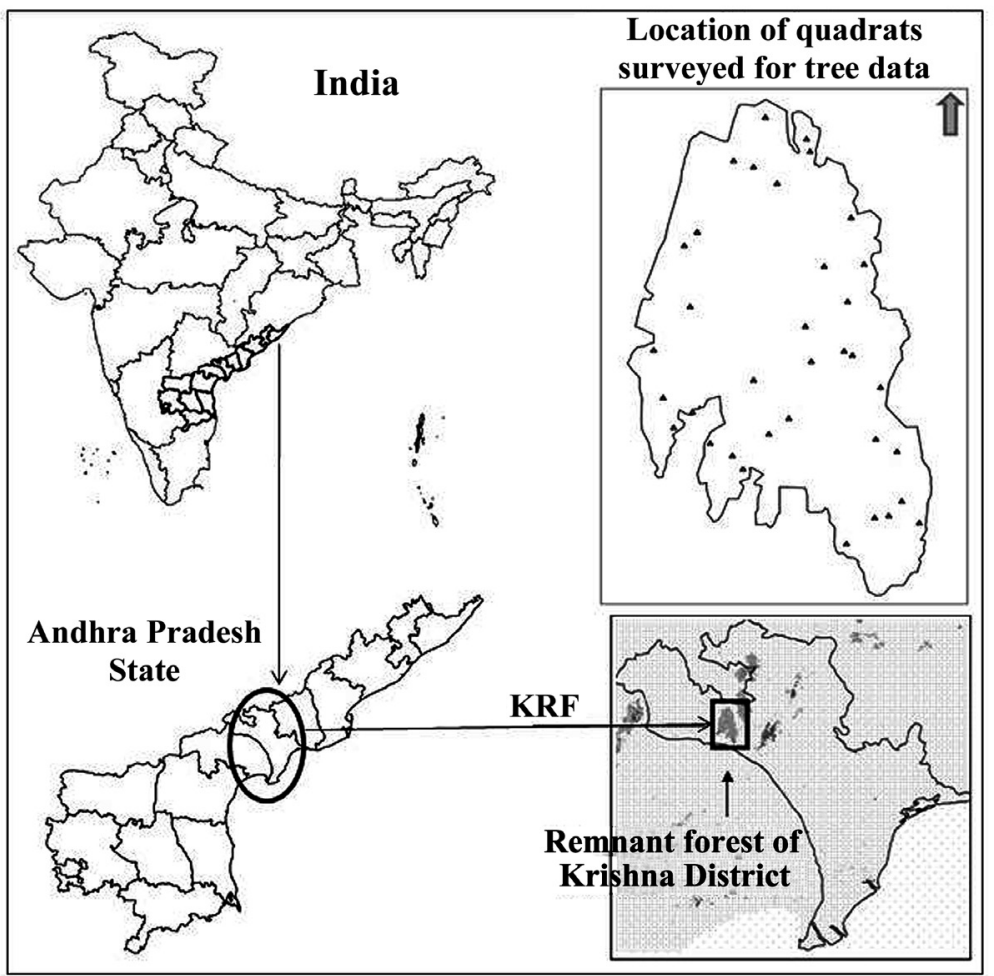

Fig. 1. Location map of the Kondapalli Reserve Forest (KRF) 

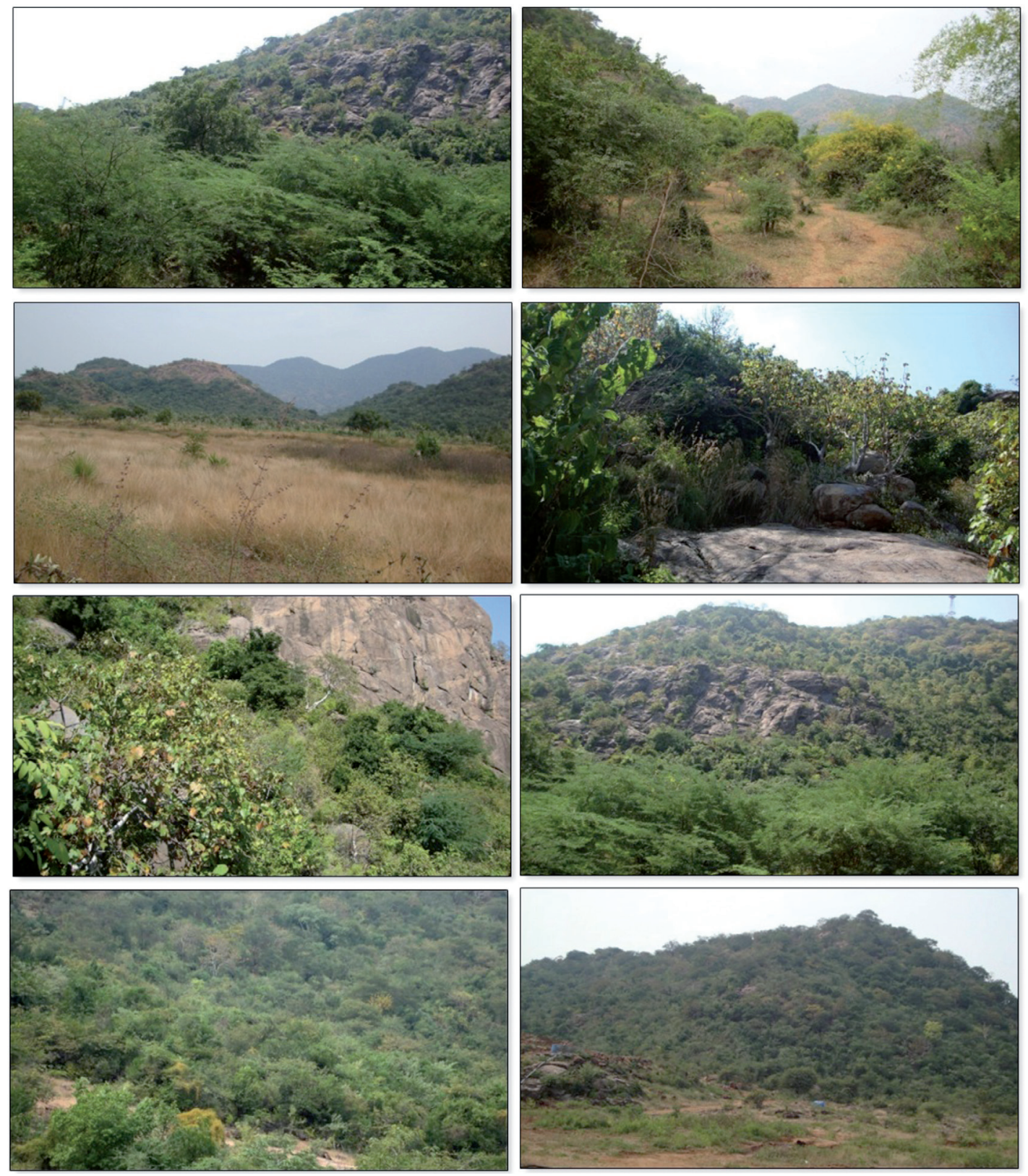

Fig. 2. Different views of tropical dry evergreen forest vegetation in the Kondapalli Reserve Forest

Champion \& Seth (1968) classified KRF as tropical dry evergreen forest-7/CI (Fig. 2). It has some unique floristic elements with bushy habit, making it difficult to enter into the forest. KRF is divided into five forest beats (sections), i.e., Kondapalli, Duggiralapadu, Jujjru, Kanchikacherla and Mullapadu. The dominant trees in this forest include Atalantia monophylla, Strychnos potatorum, Gyrocarpus americanus, Albizia amara, Givotia moluccana and Chomelia asiatica.

\subsection{Data collection}

The field work on quantitative inventory was carried out between June 2013 and May 2014. Considering the operational forest area chosen for study $(10,600 \mathrm{ha})$ and based on our reconnaissance field survey, the quadrat size was limited to $10 \times 10 \mathrm{~m}(0.01 \mathrm{ha})$ area. A total of 36 quadrats were randomly surveyed in the five forest beats based on accessibility and intactness of the forest. Degraded and open forest areas were eliminated during inventory. Geographical coordinates of quadrats were taken using a GPS device. All trees of $\geq 10 \mathrm{~cm}$ diameter at breast height (DBH) were measured at $1.3 \mathrm{~m}$ from the ground using a diameter tape. Species identification was done while carrying out the inventory with the help of a taxonomist accompanying during field visits. For unknown species, specimens were collected with proper field information (plot number, locality, habitat, etc.) and were identified with the help of literature and flora (Pullaiah \& Ramamurthy 2001; Reddy et al. 2001, Sandhyarani et al. 2007; Pullaiah \& Rao 2002). 


\subsection{Data analysis}

Species diversity was calculated using the ShannonWiener index with log base 2 (H-Shannon \& Wiener 1963), Dominance by Simpson (D-Simpson 1949) index and Evenness by Pielou (1975). The relation between diversity components was calculated using the SHE analysis equation $\mathrm{H}=\ln (\mathrm{S})+\ln (\mathrm{E})$ (Buzas \& Hayke 2005). Species richness (S) was determined by totaling the number of species in all the quadrats sampled and estimated using Jackknife1, Jackknife2 and Chao2 (Heltshe \& Forrester 1983; Smith \& Van Belle 1984; Chao 1987 respectively). The Jackknife1 considers the number of unique species, whereas the Jackknife2 and Chao2 use unique species (found in only one quadrat) and duplicate species (found in two quadrats) data and the number of quadrats sampled. To estimate the species richness, we used the EstimateS (Colwell 2004) software default settings of sampling without replacement and sampled quadrats were randomized for 1000 runs. Estimates of species richness were analyzed graphically by plotting the estimator and observed species richness as a function of cumulative number of quadrats sampled. Based on the Raunkiaer (1934) classification, heterogeneity of the forest was determined as the distribution of species in five frequency (\%) classes, i.e., $\mathrm{A}=1-20 \%$, $\mathrm{B}=21-40 \%, \mathrm{C}=41-60, \mathrm{D}=61-80 \%$ and $\mathrm{E}=81-100 \%$.

Family importance value (FIV) was calculated as the sum of relative density, relative dominance and relative diversity (Mori et al. 1983). For each species, frequency, density, basal area and abundance were computed. To understand the species share in the forest community, importance value index (IVI) was calculated as the sum of its relative dominance (RDm), relative density (RD) and relative frequency (RF) (Cottam \& Curtis 1956). The spatial distribution of species was measured using the Index of dispersion (D) using calculation of the variance to mean ratio (Selby 1965).

To understand the population structure (Rao et al. 1990), the tree data were divided into eight girth classes with $20 \mathrm{~cm}$ diameter intervals. In each girth class, species richness, diversity, stem density and basal area were analyzed. To delineate the dominant species communities occurring within the forest, a cluster analysis was performed with PAST software using Ward's method with Euclidean distance. Each cluster was delineated as a different community with dominant and co-dominant/ associated species (Caswell 1976).

\section{Results and discussion}

\subsection{Floristic structure, composition and diversity}

\subsubsection{Diversity, evenness, richness and heterogeneity}

A total of $566 \pm 16$ trees ( $\geq 10 \mathrm{~cm}$ girth) representing $46 \pm 8$ species from 40 genera and 21 families were recorded from 0.36 ha of KRF. Out of 46 species, 43 were identified as medicinally important species. The recorded Shannon (H), Simpson (D) and Evenness (E) Index values were 3.2, 0.07 and 0.58 respectively. $\mathrm{H}$ considers both $\mathrm{S}$ and $\mathrm{E}$ and is biased by sample size. Calculation of the error using the formula (S-1)/2N $(\mathrm{N}=$ sample size) showed a value of 0.04 , which is a

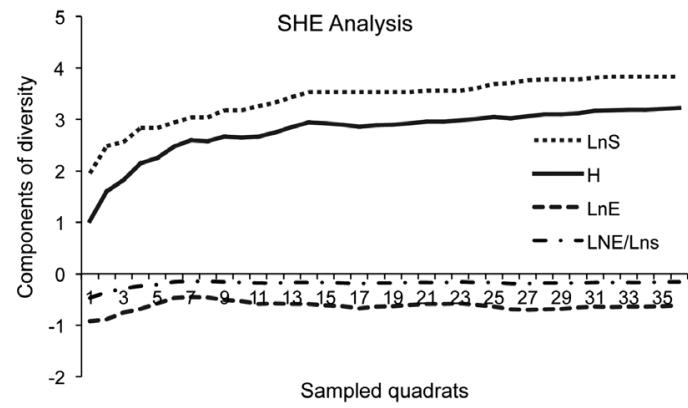

$\mathrm{c}$

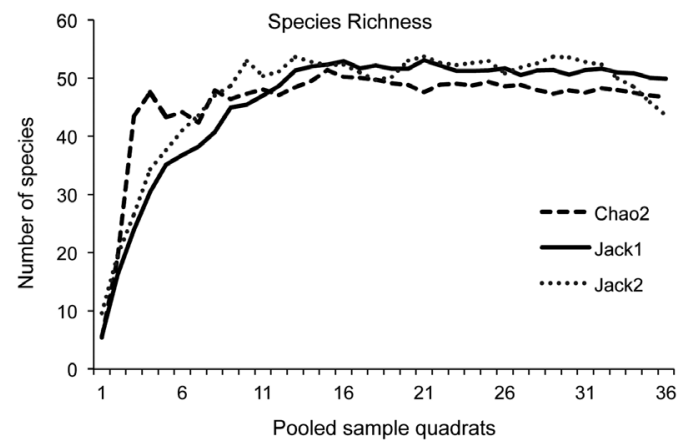

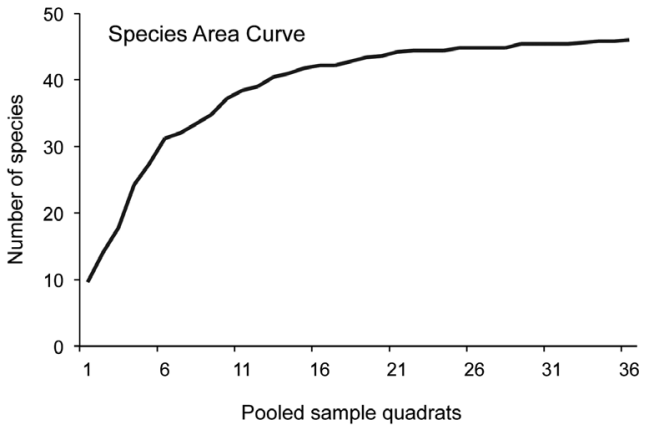

d

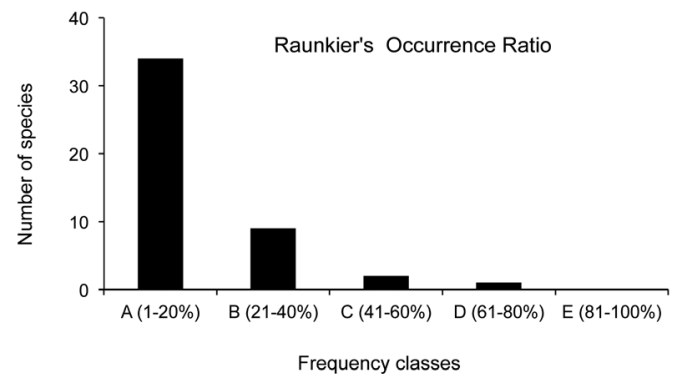

Fig. 3. Structure and diversity indices of the Kondapalli Reserve Forest 
smaller than $\mathrm{H}$, indicating that the calculated $\mathrm{H}$ is an acceptable estimate. The $\mathrm{D}$ value of 0.07 indicates a heterogeneous community and $\mathrm{E}$ value $(0.58)$ represents the abundance of a few species in the forest. In addition, the Simpson index of diversity was obtained by subtracting the $\mathrm{D}$ value from $1(1-\mathrm{D}$ i.e. $1-0.07=0.93)$. For $\mathrm{D}$, value approaching 1 indicates a highly homogenous community, while for the Simpson diversity Index values approaching 1 is a high species diversity community. Simpson diversity is less sensitive to species richness and more to evenness, while $\mathrm{H}$ shows a reverse trend (Colwell 2009).

Furthermore, SHE analysis provided a better understanding about the relationship between $\mathrm{S}, \mathrm{H}$, and E within the KRF community (De Benedictis 1973; Stirling \& Wilsey 2001; Fig. 3a). The diversity indices, $\mathrm{S}$ and $\mathrm{H}$ showed an increased trend, while E showed negative values or the reverse. As the sample number increased, both $\mathrm{S}$ and $\mathrm{H}$ showed maximum value $>3$, while it was low for $\mathrm{E}$. The constant $\ln \mathrm{E} / \mathrm{S}$ and $\mathrm{H}$ with the increasing number of samples indicate the characteristic structure of forest between lognormal and log series distribution, which is a common feature of forest community with the low number of abundant species (Magurran 2004; Reshi et al. 2009). The E (0.58) value recorded in the present study also confirms this statement.
The observed species richness curve declined with increased sampling area and gradually reached an asymptote (Fig. 3b). The curve started flattening at an area of 0.29 ha. This indicates that the sampled area ( $0.36 \mathrm{ha})$ is sufficient to capture the species richness of KRF. The species richness predicted by estimators Chao2, Jackknife1 and Jackknife2 was 47, 50 and 44 species, respectively (Fig. 3c). The bias observed in species richness estimations either positive (over-47/50 species) or negative (under 44) is smaller compared to actual observed species (46) obtained from the field data. Among the three estimators, Jackknife 1 was found to be best as it reached $\mathrm{S}_{\max }$ quickly at 0.14 ha and remained relatively constant. In conclusion, the predicted species richness number in KRF is 50 compared to observed richness of 46 . However, as suggested by Kotz \& Johnson (1982-1988) and Stuart \& Ord (1991), a good estimator is the one that estimates the values nearer to the true values. In such case, Chao 2 can be considered a better estimator with the predicted species number of 47 that is closest to the true value observed from the inventory (46).

The frequency of Raunkiaer's classes followed the pattern $\mathrm{A}>\mathrm{B}>\mathrm{C}>>\mathrm{D}>\mathrm{E}$. As per Raunkiaer, when classes $\mathrm{A} \mathrm{B}, \mathrm{C}, \mathrm{D}$ are high, the community is considered to be heterogeneous; on the other hand, if the class $\mathrm{E}$ is greater than another, it is a uniform or homogenous community.

Table. 1. Family importance values found for the Kondapalli Reserve Forest in decreasing order

\begin{tabular}{|c|c|c|c|c|c|c|c|c|c|}
\hline No. & Family & Individuals & $\begin{array}{c}\text { BA } \\
\mathrm{m}^{2} \mathrm{ha}^{-1}\end{array}$ & Species & Genera & $\mathrm{RD}$ & $\mathrm{RDm}$ & $\mathrm{RDv}$ & FIV \\
\hline 1 & Mimosaceae & 76 & 1.30 & 9 & 4 & 13 & 8 & 19.6 & 40.6 \\
\hline 2 & Rutaceae & 122 & 1.84 & 3 & 3 & 22 & 11 & 6.5 & 38.9 \\
\hline 3 & Rubiaceae & 61 & 1.66 & 5 & & 11 & 10 & 10.9 & 31.4 \\
\hline 4 & Loganiaceae & 58 & 1.43 & 2 & 1 & 10 & 8 & 4.3 & 23.0 \\
\hline 5 & Meliaceae & 10 & 2.26 & 2 & 2 & 2 & 13 & 4.3 & 19.4 \\
\hline 6 & Euphorbiaceae & 38 & 1.33 & 2 & 2 & 7 & 8 & 4.3 & 18.9 \\
\hline 7 & Burseraceae & 26 & 1.58 & 1 & 1 & 5 & 9 & 2.2 & 16.1 \\
\hline 8 & Hernandiaceae & 38 & 1.07 & 1 & 1 & 7 & 6 & 2.2 & 15.2 \\
\hline 9 & Myrtaceae & 5 & 1.88 & 1 & 1 & 1 & 11 & 2.2 & 14.1 \\
\hline 10 & Papilionaceae & 20 & 0.29 & 4 & 3 & 4 & 2 & 8.7 & 13.9 \\
\hline 11 & Apocynaceae & 21 & 0.40 & 3 & 3 & 4 & 2 & 6.5 & 12.6 \\
\hline 12 & Caesalpiniaceae & 12 & 0.35 & 2 & 2 & 2 & 2 & 4.3 & 8.5 \\
\hline 13 & Sapindaceae & 15 & 0.15 & 2 & 2 & 3 & 1 & 4.3 & 7.9 \\
\hline 14 & Combretaceae & 11 & 0.23 & 2 & 2 & 2 & 1 & 4.3 & 7.6 \\
\hline 15 & Fabaceae & 7 & 0.52 & 1 & 1 & 1 & 3 & 2.2 & 6.5 \\
\hline 16 & Anacardiaceae & 13 & 0.20 & 1 & 1 & 2 & 1 & 2.2 & 5.6 \\
\hline 17 & Santalaceae & 12 & 0.11 & 1 & 1 & 2 & 1 & 2.2 & 4.9 \\
\hline 18 & Moringaceae & 7 & 0.23 & 1 & 1 & 1 & 1 & 2.2 & 4.8 \\
\hline 19 & Sterculiaceae & 7 & 0.07 & 1 & 1 & 1 & 0 & 2.2 & 3.8 \\
\hline 20 & Lecythidaceae & 5 & 0.06 & 1 & 1 & 1 & 0 & 2.2 & 3.4 \\
\hline \multirow[t]{2}{*}{21} & Sapotaceae & 2 & 0.02 & 1 & 1 & 0 & 0 & 2.2 & 2.6 \\
\hline & Total & 566 & 16.98 & 46 & 40 & 100 & 100 & 100 & 300 \\
\hline
\end{tabular}

Explanations: BA - basal area, RD - relative density, RDm - relative dominance, RDv - relative diversity, FIV - family importance value 
As observed (Fig. 3d), the majority of species are found in the lower frequency class $\mathrm{A}=1-20 \%$ (34), representing the heterogeneous nature of the forest community in concurrence with D (Simpson) values. Overall, the value of $\mathrm{D}, 1-\mathrm{D}$ and $\mathrm{H}$ indicates $\mathrm{KRF}$ as heterogeneous and diverse community in relation to its size.

\subsubsection{Family and species dominance}

Mimosaceae was the most species rich family with nine species, followed by Rubiaceae (five species), Papilionaceae (four species), Rutaceae and Apocynaceae ( 3 species each). Out of 21 families, 10 families were represented by only one species. Within Mimosaceae, the genus Acacia was represented by four species, $A l$ bizia by three and Samania and Xylia by one species, respectively. Of the recorded families, Rutaceae was the most abundant family with 122 individuals, while Sapotaceae was represented by only two individuals belonging to Manilkara hexandra. The family Rutaceae accounted for $22 \%$ of tree density, followed by Mimosaceae $(13 \%)$ and Rubiaceae (11\%), which summed up to $46 \%$ of the total tree density. About $13 \%$ of the basal area was contributed to the family Meliaceae, followed by Myrtaceae (11\%) and Rutaceae (11\%). These three families together constituted $35 \%$ of the total forest basal area. The maximum FIV value was observed for Mimosaceae (40.6) followed by Rutaceae (38.9), Rubiaceae (31.4), Loganiaceae (23.0) and Meliaceae (19.4), together accounting for $50 \%$ of total FIV (Table 1).

Atalantia monophylla was the most frequent and abundant species represented by 113 individuals out of 566 and provided $20 \%$ of the total tree density, followed by Strychnos potatorum (41). With respect to basal area, Melia azedarach and Syzygium cumini were the dominant species contributing to 13 and $11 \%$ of the total basal area. In terms of species importance based on IVI, Atalantia monophylla recorded a high value of 38.10, followed by Strychnos potatorum (19.33), Commiphora caudate (19.02), Gyrocarpus americanus (18.86), and Givotia moluccana (16.36), together contributing 37\% to overall IVI (Table 2). Low value of IVI was recorded for Pongamia pinnata. The observed dominance of particular species may be due to their optimal resource use, dispersal mechanism, function of stress and disturbances that create more space with high competition and exclusive growth (Wisheu \& Keddy 1992; Richards 1996; Allison \& Vitousek 2004).

\subsubsection{Stem density and basal area}

The recorded stem density is 1572 stems ha $^{-1}$. Out of 46 species, 39 species were represented by $<17$ individuals and 7 species $>26$. About $21 \%$ of the species were represented as single and two individuals (8) falling under the category of rare species. Probably they may be the victims of local extinction owing to their small populations (Primack \& Hall 1992). About 45.4\% of the stem density is contributed by top five species, i.e., Atalantia monophylla (314), Strychnos potatorum (114), Gyrocarpus americanus (105), Albizia amara (97) and Givotia moluccana (83). The mean basal area of the forest is $47.17 \mathrm{~m}^{2} \mathrm{ha}^{-1}$. Maximum DBH was recorded for Melia azedarach $(450 \mathrm{~cm})$ followed by Syzygium cumini $(361 \mathrm{~cm})$. The top five species contributing $50 \%$ of basal area include: Melia azedarach (6\%), Syzygium cumini (5.2\%), Atalantia monophylla (4.8\%), Commiphora caudate (4.4\%), and Mytragyna parviflora (3.4\%).

\subsubsection{Species spatial pattern}

Out of 46 species, 25 species showed clumped and 21 random spatial distribution. The dispersion pattern of species is mainly governed by their interaction with the physical environment/microclimatic conditions (Diggle 1983; Armesto et al. 1986,), the availability of resources and competition among species, mainly in their seed dispersal mechanism (Seidler \& Plotkin 2006). Populations of species with cluster dispersion

Table 2. Importance value indices of species recorded in the Kondapalli Reserve Forest

\begin{tabular}{|c|c|c|c|c|c|c|c|c|c|c|}
\hline No. & Species Name & Individuals & Abundance & Frequency & Density & $\begin{array}{c}\text { BA } \\
\mathrm{m}^{2} \mathrm{ha}^{-1}\end{array}$ & $\mathrm{RF}$ & $\mathrm{RD}$ & RDm & IVI \\
\hline 1 & $\begin{array}{l}\text { Atalantia monophylla (L.) } \\
\text { DC. }\end{array}$ & 113 & 514 & 61.11 & 313.89 & 1.716 & 8.03 & 19.96 & 10.11 & 38.1 \\
\hline 2 & Strychnos potatorum L.f. & 41 & 293 & 38.89 & 113.89 & 1.185 & 5.11 & 7.24 & 6.98 & 19.33 \\
\hline 3 & $\begin{array}{l}\text { Commiphora caudata } \\
\text { (Wight \& Arn.) Engl. }\end{array}$ & 26 & 186 & 38.89 & 72.22 & 1.584 & 5.11 & 4.59 & 9.33 & 19.03 \\
\hline 4 & $\begin{array}{l}\text { Gyrocarpus americanus } \\
\text { Jacq. }\end{array}$ & 38 & 238 & 44.44 & 105.56 & 1.072 & 5.84 & 6.71 & 6.31 & 18.86 \\
\hline 5 & $\begin{array}{l}\text { Givotia moluccana (L.) } \\
\text { Sreem. }\end{array}$ & 30 & 273 & 30.56 & 83.33 & 1.198 & 4.01 & 5.3 & 7.05 & 16.37 \\
\hline 6 & Melia azedarach L. & 8 & 133 & 16.67 & 22.22 & 2.146 & 2.19 & 1.41 & 12.64 & 16.24 \\
\hline
\end{tabular}


7 Albizia amara (Roxb.) B Boivin

8 Syzygium cumini (L.) Skeels 35

9 Mitragyna parviflora (Roxb.) Korth.

10 Chomelia asiatica (L.) Kuntze

11 Strychnos nux-vomica $\mathrm{L}$.

12 Tamarindus indica $\mathrm{L}$.

13 Acacia auriculiformis Benth.

14 Dalbergia paniculata (Roxb.) Thoth.

15 Schleichera oleosa (Lour.) Oken.

16 Santalum album L.

17 Wrightia tinctoria R. Br.

18 Cassia fistula L.

19 Canthium dicoccum (Gaertn.) Merr.

20 Lannea coromandelica (Houtt.) Merr.

21 Acacia chundra (Rottler) Willd.

22 Morinda pubescens Sm.

23 Anogeissus latifolia (DC.) Wallich ex Guill. \& Perr.

24 Moringa concanensis Nimmo

25 Phyllanthus reticulates Poir.

26 Holarrhena pubescens Wall. ex G. Don

27 Albizia lebbeck (L.) Benth.

28 Aegle marmelos (L.) Correa.

29 Pterospermum canescens (Roxb.)

30 Sesbania grandiflora (L.) Poiret

31 Ixora pavetta Andr.

32 Samanea saman F. Muell.

33 Careya arborea Roxb.

34 Bauhinia racemosa Lam.

35 Azadirachta indica A. Juss.

36 Xylia xylocarpa (Roxb.) Taub.

37 Sapindus emarginatus Vahl

38 Chloroxylon swietenia (Roxb.) DC.

39 Acacia ferruginea DC.

$40 \quad$ Acacia concinna (Willd.)

DC.

41 Dalbergia latifolia (Roxb.)

42 Terminalia arjuna (Roxb.) Wight \& Arn.

43 Manilkara hexandra (Roxb.) Dubard

44 Albizia odoratissima (L.f.) Benth.

45 Plumeria alba L.

46 Pongamia pinnata Pierre
5

12

167

171

175

28

15

155

117

110

11

12

12

150

133

150

325

143

129

325

13

11

8

9

7

8

7

6

6

7

5

183

114

225

175

200

140

120

120

175

125

133

100

250

200

100

200

150

150

100

150

100

100

100

100

100

100
36.11

8.33

19.44

44.44

30.56

16.67

27.78

22.22

25

22.22

11.11

19.44

19.44

11.11

16.67

19.44

11.11

11.11

11.11

13.89

13.89

13.89

11.11

11.11

8.33

5.56

5.56

2.78

5.56

5.56

5.56

5.56

5.56

5.56

5.56

5.56

5.56

19.44

22.22

19.44

16.67

16.67

19.44

13.89

11.11

5.56

13.89

5.56

5.56

11.11

8.33

8.33

5.56

8.33

0.089

0.02

$\begin{array}{ll}5.56 & 0.031\end{array}$

5.56

0.029

0.73

0.73

5.56

0.018

0.73

5.56

5.56

0.012

0.73

2.78

2.78

2.78

2.78

0.004

0.36 0.002

0.36

5.84

4.01

2.92

3.28

2.92

2.55

19

$\begin{array}{lll}6.18 & 4.03 \quad 14.96\end{array}$

$\begin{array}{lll}0.88 & 11.08 & 13.06\end{array}$

$\begin{array}{lll}2.12 & 7.31 & 11.98\end{array}$

$4.95 \quad 0.63$

11.41

$3 \quad 1.46$

8.48

$\begin{array}{llll}2.19 & 1.24 & 3.05 & 6.48\end{array}$

$\begin{array}{llll}3.65 & 1.94 & 0.64 & 6.23\end{array}$

$2.12 \quad 0.88$

5.92

$2.12 \quad 0.43$

5.83

$2.12 \quad 0.65$

5.69

$2.3 \quad 1.85$

5.61

5.34

$1.77 \quad 1.0$

4.96

4.91

1.94

0.65

4.78

Explanations: $\mathrm{BA}$ - basal area, $\mathrm{RF}$ - relative frequency, $\mathrm{RD}$ - relative density, $\mathrm{RDm}$ - relative dominance, $\mathrm{IVI}$ - importance value index 

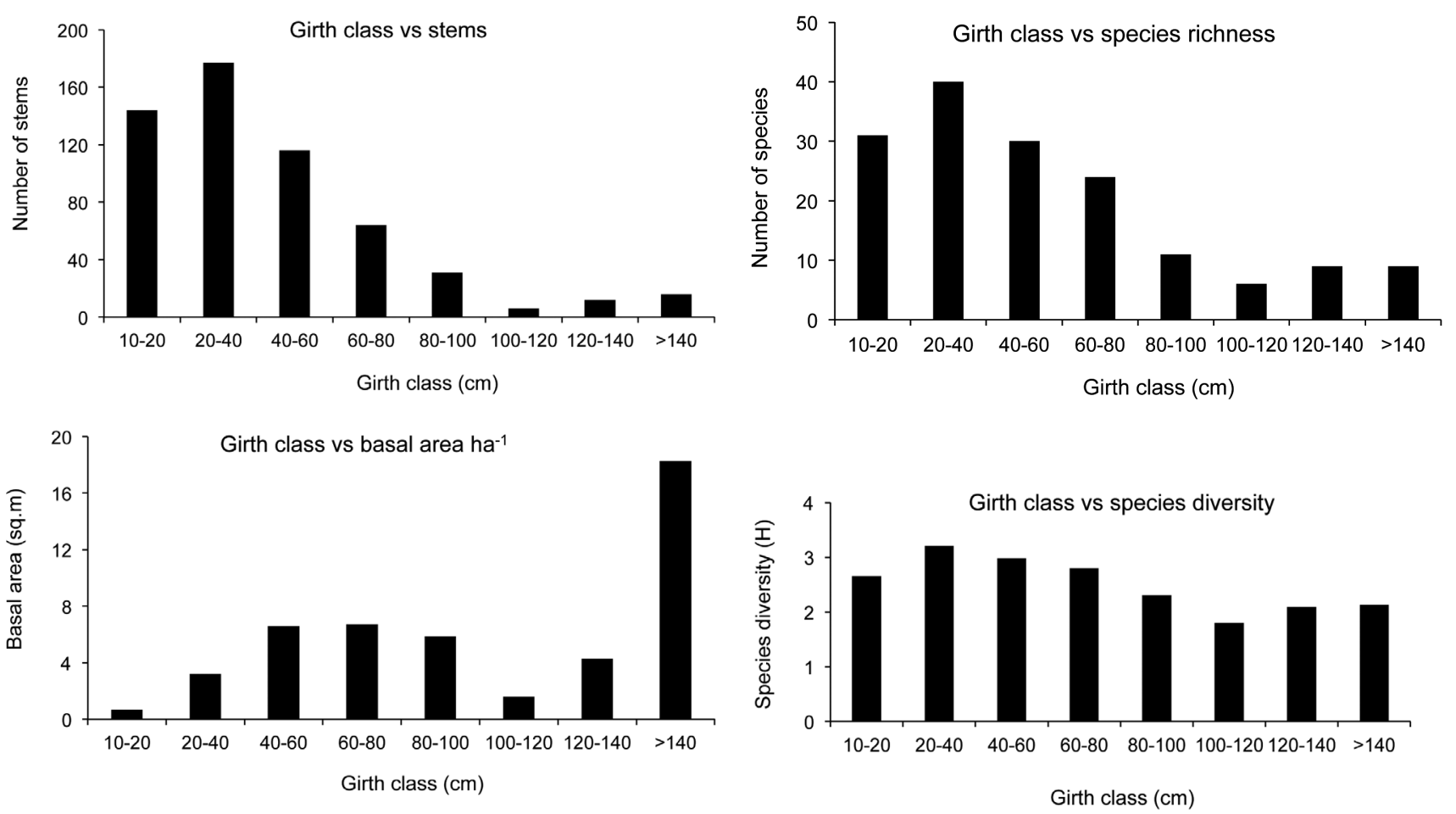

Fig. 4. Stem density, basal area, species richness and diversity among the girth classes in the Kondapalli Reserve Forest

show the negative binomial distribution, while these with random pattern follow a Poisson distribution. Generally, clustered distribution is common in nature (Odum 1971), compared to random, and is also a function of spatial scale (Hurlbert 1990). According to Leps \& Kindlmann (1987), a random pattern is mostly exhibited by mature plants, though they tend to show a cluster pattern at their seedling stage. It is assumed that the neighborhood competition among the seedlings finally changes a dispersion pattern from cluster to random. This indicates that the spatial patterns of individuals are dynamic and change at varying spatial scales, as well as at different developmental stages (Yi et al. 2008).

\subsubsection{Tree girth analysis}

An assessment of tree diameter distribution often reflects the disturbing effect (Denslow 1995; RamirezMarcial et al. 2001), as well as resource utilization by species within a forest (Hitimana et al. 2004). In the studied area, species richness, diversity and stem density decreased with increasing girth class, except in $10-20 \mathrm{~cm}, 100-120 \mathrm{~cm}$ and $120-140 \mathrm{~cm}$ girth classes (Fig. 4). This could be due to preferential logging of these girth class woods by local people. Such type of logging modifies forest structure, species composition and diversity (Smiet 1992; Cazzolla et al. 2015). About $77 \%$ of the recorded stems were from lower girth classes of 10-60 cm. The tree girth exhibited positively skewed asymmetrical distribution within the studied population.
This represents the forest as mature and expanding type with a high contribution of trees from the lower girth classes. Relatively high species richness (87\%) and diversity (3.2) were found in $20-40 \mathrm{~cm}$ girth class (Fig. 4). Interestingly the girth class of $100-120 \mathrm{~cm}$, comprised six species represented by six individuals. In terms of basal area, no particular trend was observed, indicating low values of girth classes similar to stem density. Overall, this analysis highlights the signs of anthropogenic disturbances in the study area by selective logging of wood.

\subsubsection{Cluster analysis}

Overall 36 quadrats were clustered into 7 groups with varied species composition based on their species similarity distance (Fig. 5). Cluster 1 and 5 are represented by a single quadrat, while 13 quadrats were grouped under cluster 3 , forming a large group. Cluster $\mathrm{C} 1$ is represented by Atalantia monophylla and Lannea coromandelica, C2: Atalantia monophylla Strychnos potatorum, Wrightia tinctoria, C3: Gyrocarpus americanus, Commiphora caudate, C4: Albizia amara and Givotia moluccana, C5: Givotia moluccana C6: Atalantia monophylla, and Chomelia asiatica, and C7: Albizia amara, Atalantia monophylla and Strychnos potatorum. Finally, it can be interpreted that Atalantia monophylla has high ecological amplitude with a wide distribution in the study area, associated with different species in KRF. 


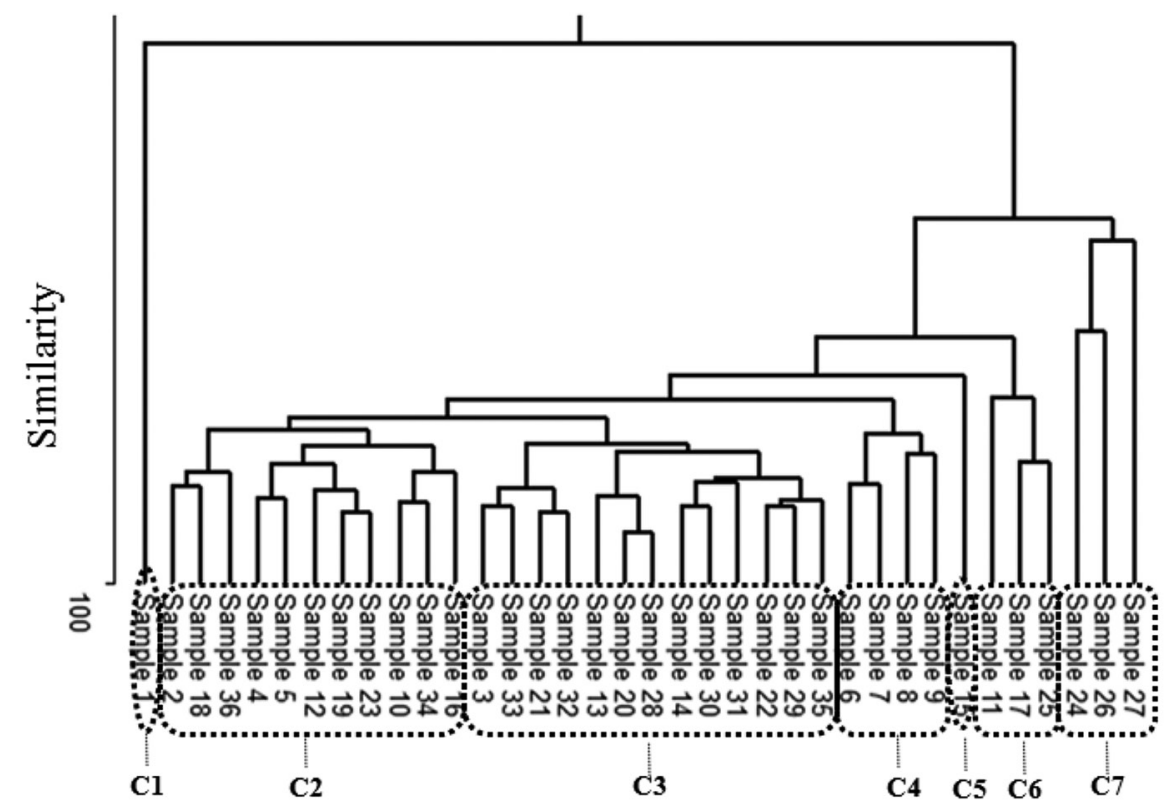

Fig. 5. Demarcating dominant species communities of the Kondapalli Reserve Forest using cluster analysis

3.2. Is it apt to compare ecosystems growing under dissimilar environmental conditions?

Edaphic and climatic factors, along with topography, influence species richness, diversity and dominance of an ecosystem beside human interferences (Huang et al. 2003; Prasad et al. 2007; Amissah et al. 2014). Also, as stated by Denslow \& Hughes (2004), species richness varies depending on the dominant species in a community. Every ecosystem on the earth is unique by itself and the current climax communities observed globally are the summation of natural and anthropogenic interactions. All the ecosystems across the world have been subjected to such interferences, and the only difference is the level of interactions, some might have encountered high and others low. Ultimately, such interactions stabilize the species richness and diversity of a given ecosystem.

So far, in the traditional ecological studies, researchers worldwide, due to an oversight, often compare species diversity parameters of one forest with another forest. In some cases, the comparison is made between evergreen and deciduous systems that are totally different both in terms of their growing conditions as well as species composition. There is also variation in the method of sampling (transect/quadrat; random or contiguous, temporary or permanent plot), sampled area, tree girth size measured, as well as the season, but despite these differences, these ecosystems are compared. The crucial comparison involves species diversity. Most of researchers globally adopt the Shannon-Wiener Index for calculation of species diversity.

$$
H=-\sum_{i=1}^{S} p_{i} \ln \left(p_{i}\right) \quad \text { Or } \quad H=-\sum_{i=1}^{S}(n i / N) \ln (n i / N)
$$

However, when comparing the results, sufficient attention is not always given to whether the diversity was calculated using natural logarithm $(\ln ), \log _{2}$ or $\log _{10}$ (Prasad \& Rajan 2014). Sometimes, it is even more confusing, e.g, Padalia et al. (2004) described the Shannon-Wiener index formula as:

$$
H=-\sum\left[(n i / N) \log _{2}(n i / N)\right](\log \text { implies to log base 10) }
$$

This formula does not provide any clue whether authors used $\log _{2}$ or $\log _{10}$. The results of this study were compared by Shruthakeerthiraja \& Kumar (2012), who used $l n$ for diversity calculation (see Prasad \& Rajan 2014 for more details). Depending on the $\ln$ and the $\log$ base $(2,10)$ value diversity values differ for the same region. For example, in the present study diversity value is 3.2 (using $l n$ ) and 4.6 (using $\log _{2}$ ).

Similarly, proper attention should be paid when comparing stem density and basal area - these attributes mostly depend on the availability of resources, dispersal capacity of the species, their spatial dispersion patterns, topography and, more specifically, logging of stems by humans or any other disturbance factor. In a region where there is high pressure of anthropogenic interference for timber products, the stem density will be obviously low. So while making comparison with other forest systems, it is essential to understand the disturbance factor that actually gives low or high values.

This type of comparative evaluations does not seem to be appropriate, because environmental conditions are different for different forest types. However, despite such a variation, it has become a custom in the diversity/ecological analysis. Even with the same forest 
Table 3. Species richness and diversity parameters in different tropical dry evergreen forests of southern India

\begin{tabular}{|c|c|c|c|c|c|c|c|c|c|}
\hline No. & Location & $\begin{array}{l}\text { MAT } \\
\left({ }^{\circ} \mathrm{C}\right)\end{array}$ & $\begin{array}{l}\text { MAR } \\
(\mathrm{mm})\end{array}$ & Plot size & $\begin{array}{l}\text { Girth } \\
(\mathrm{cm})\end{array}$ & $\mathrm{S}$ & $\mathrm{H}$ & $\begin{array}{c}\text { Stems } \\
\text { ha }^{-1}\end{array}$ & $\begin{array}{c}\text { BA } \\
\mathrm{m}^{2} \mathrm{ha}^{-1}\end{array}$ \\
\hline 1 & *Kondapalli RF & 28.5 & 1067 & 36 plots of 0.01 ha $(10 \times 10 \mathrm{~m})$ & $\geq 10$ & 46 & 3.2 & 1572 & 47.17 \\
\hline 2 & ${ }^{\mathrm{a}}$ Guindy National Park & --- & --- & $\begin{array}{l}200 \times 200 \mathrm{~m} \text { quadrat area } \\
\text { In each } 80 \text { quadrats of } 5 \times 5 \mathrm{~m}\end{array}$ & $\geq 20$ & 31 & 2.94 & --- & --- \\
\hline 3 & ${ }^{\mathrm{b}}$ Marakkanam RF & --- & 1254 & Three 0.1 ha $(20 \times 50 \mathrm{~m})$ & $\geq 20$ & --- & $\begin{array}{l}0.83- \\
2.43\end{array}$ & 280 & 11 \\
\hline 4 & ${ }^{\mathrm{b}}$ Puthupet SG & --- & $"$ & Two 0.1 ha & $"$ & --- & $\begin{array}{l}1.47- \\
1.59\end{array}$ & 1130 & 36 \\
\hline 5 & ${ }^{\mathrm{c}}$ Suriyampettai & --- & --- & --- & --- & 28 & 1.61 & --- & 21.54 \\
\hline 6 & ${ }^{\mathrm{d}}$ Puthupet & --- & --- & $\begin{array}{l}\text { Four } 0.5 \text { ha plots. } 100 \times 50 \mathrm{~m} \\
\qquad(10 \times 10 \mathrm{~m})\end{array}$ & $\geq 10$ & 51 & 2.28 & 1338 & 32.78 \\
\hline 4 & ${ }^{\mathrm{e}}$ Kuzhanthaikuppam & 28.5 & 1378 & Two 1-ha $(100 \times 100 \mathrm{~m})$ plots, & $\geq 10$ & 42 & 2.35 & 1367 & 15.44 \\
\hline 5 & ${ }^{\mathrm{e}}$ Thirumanikkuzhi & $"$ & $"$ & divided into $10 \times 10 \mathrm{~m}$ & $"$ & 38 & 2.57 & 974 & 29.48 \\
\hline 6 & ${ }^{\mathrm{f}}$ Oorani & --- & 1373 & 25 plots of $20 \times 20 \mathrm{~m}$ & $\geq 20$ & 30 & 2.08 & 1070 & 25.55 \\
\hline 7 & ${ }^{\mathrm{f}}$ Olagapuram & --- & $"$ & adding to 1 ha in each site & $"$ & 21 & 2.42 & 953 & 4.31 \\
\hline 8 & ${ }^{f}$ Oorani & 28.5 & 1311 & $\begin{array}{l}\text { One ha plot }(100 \times 100 \mathrm{~m}) \\
\text { subdivided } \\
\text { into } 100,10 \times 10 \mathrm{~m} \text { quadrats }\end{array}$ & $"$ & 31 & 1.82 & 2815 & 17.63 \\
\hline 9 & ${ }^{\mathrm{f}}$ Olagapuram & $"$ & $"$ & $\begin{array}{c}\text { Two } 200 \times 25 \mathrm{~m} \text { plots, divided } \\
\text { into } 40 \\
(10 \times 10 \mathrm{~m}) \text { and } 20(5 \times 10 \mathrm{~m}) \\
\text { quadrats }\end{array}$ & $"$ & 30 & 2.33 & 1286 & 27.3 \\
\hline 10 & ${ }^{\mathrm{h}}$ Araiyapatti (LD) & 28.5 & 1378 & & $\geq 10$ & 35 & 2.44 & 8.7 & 19.1 \\
\hline 11 & ${ }^{\mathrm{h}}$ Karisakkadu (MD) & $"$ & $"$ & & $"$ & 30 & 2.24 & 596 & 21.6 \\
\hline 12 & ${ }^{\mathrm{h}}$ Maramadakki (HD) & $"$ & $"$ & & $"$ & 28 & 2.01 & 724 & 15.5 \\
\hline 13 & $\begin{array}{l}\text { hShanmuganathapuram } \\
\text { (MD) }\end{array}$ & $"$ & $"$ & 1 ha permanent plot & $"$ & 26 & 1.29 & 1663 & 22.1 \\
\hline 14 & hRayapatti (MD) & $"$ & $"$ & $(100 \times 100 \mathrm{~m})$ in each site, & $"$ & 19 & 1.84 & 886 & 12.4 \\
\hline 15 & hPuthupet (HD) & $"$ & $"$ & divided into $(10 \times 10 \mathrm{~m})$ & $"$ & 30 & 1.64 & 1567 & 36.5 \\
\hline 16 & ${ }^{\mathrm{h}}$ Oorani (MD) & $"$ & $"$ & quadrats & $"$ & 29 & 2.33 & 1284 & 27.3 \\
\hline 17 & ${ }^{\mathrm{h}}$ Arasadikuppam (MD) & $"$ & $"$ & & $"$ & 30 & 1.82 & 2813 & 17.6 \\
\hline 18 & $\begin{array}{l}\text { hKuzhanthaikuppam } \\
\text { (MD) }\end{array}$ & $"$ & $"$ & & $"$ & 28 & 2.02 & 1349 & 16.9 \\
\hline 19 & hThirumanikkuzhi (MD) & " & $"$ & & $"$ & 22 & 2.06 & 1077 & 29.3 \\
\hline 20 & $\begin{array}{l}{ }^{i} \text { Kuzhanthaikuppam } \\
(1995-2005)\end{array}$ & 28.5 & 1378 & Two 1-ha $(100 \times 100 \mathrm{~m})$ plots, & $\geq 10$ & $\begin{array}{l}26- \\
24\end{array}$ & $\begin{array}{l}2.07- \\
2.14\end{array}$ & $\begin{array}{l}1229- \\
1032\end{array}$ & $\begin{array}{l}14.6- \\
14.9\end{array}$ \\
\hline 21 & $\begin{array}{l}\text { 'Thirumanikkuzhi } \\
(1995-2005)\end{array}$ & $"$ & $"$ & $\begin{array}{l}\text { subdivided into } 10 \times 10 \mathrm{~m} \\
\text { subplots }\end{array}$ & $"$ & $\begin{array}{l}26- \\
22\end{array}$ & $\begin{array}{l}2.23- \\
2.11\end{array}$ & $\begin{array}{l}832- \\
978\end{array}$ & $28.9-27$ \\
\hline 22 & ${ }^{\mathrm{j} A}$ Araiyapatti (HD) & 29.5 & 1033 & & $\geq 10$ & 37 & 2.56 & 705 & 19.43 \\
\hline 23 & ${ }^{\mathrm{j} K a r i s a k k a d u}(\mathrm{MD})$ & $"$ & $"$ & Four 1 ha permanent plots & $"$ & 31 & 2.52 & 596 & 20.26 \\
\hline 24 & ${ }^{\mathrm{j} M a r a m a d a k k i(M D)}$ & $"$ & $"$ & $(100 \times 100 \mathrm{~m}) ; 10 \times 10 \mathrm{~m}$ & $"$ & 27 & 2.11 & 750 & 18.63 \\
\hline 25 & $\begin{array}{l}\text { jShanmuganathapuram } \\
\text { (HD) }\end{array}$ & $"$ & $"$ & & $"$ & 29 & 1.54 & 1182 & 20.38 \\
\hline 26 & $\begin{array}{l}\text { kPuducherry, Villupuram, } \\
\text { Pudukottai }\end{array}$ & Cuddalore, & & & $\geq 10$ & & & & \\
\hline 27 & RUD & 32.9 & 1282 & & $"$ & 69 & 3.13 & $\begin{array}{l}193- \\
274\end{array}$ & $\begin{array}{l}2.82- \\
7.62\end{array}$ \\
\hline 28 & MD & --- & --- & $\begin{array}{c}100 \text { plots of size } \\
10 \times 20 \mathrm{~m}\end{array}$ & $"$ & 57 & 2.8 & $\begin{array}{c}124- \\
297\end{array}$ & $\begin{array}{l}1.73- \\
9.76\end{array}$ \\
\hline 29 & MU & 33.6 & 1079 & in four disturbance classes & $"$ & 54 & 2.99 & $\begin{array}{l}90- \\
208\end{array}$ & $\begin{array}{l}1.75- \\
5.42\end{array}$ \\
\hline 30 & HD & 33.4 & 1033 & & $"$ & 46 & 2.24 & $\begin{array}{l}62- \\
109\end{array}$ & $\begin{array}{l}0.55- \\
3.98\end{array}$ \\
\hline 31 & ${ }^{1}$ Suryanpet & 29.5 & 1141 & & $\geq 10$ & 26 & 2.13 & 771 & 32.55 \\
\hline 32 & ${ }^{1}$ Velleripet & $"$ & $"$ & One ha plot in each site, & $"$ & 18 & 1.24 & 1144 & 47.84 \\
\hline 33 & ${ }^{\text {'S. Pudhoor }}$ & $"$ & $"$ & divided into $10 \times 10 \mathrm{~m}$ & $"$ & 25 & 1.3 & 1145 & 17.74 \\
\hline 34 & ${ }^{1}$ Chinna Kumatti & $"$ & $"$ & & $"$ & 27 & 2.2 & 1285 & 36.7 \\
\hline 35 & mPuthupet & $"$ & $"$ & $\begin{array}{l}\text { Four } 0.5 \text { ha }(100 \times 50 \mathrm{~m} \text {; total } \\
\qquad 2 \mathrm{ha})\end{array}$ & $\geq 10$ & 23 & --- & 1329 & 37.5 \\
\hline
\end{tabular}




\begin{tabular}{|c|c|c|c|c|c|c|c|c|}
\hline${ }^{n}$ Vidathudaiyar SG & 40 & 2043 & \multirow{3}{*}{1 ha plot } & $\geq 30$ & 65 & 1.9 & 14 & 7.72 \\
\hline${ }^{\mathrm{n} K o o d a i y a k k a r u p p a r ~ S G}$ & $"$ & $"$ & & $"$ & 55 & 1.69 & 8 & 6.55 \\
\hline 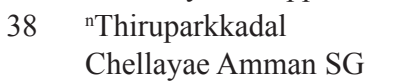 & $"$ & $"$ & & $"$ & 68 & 2.33 & 15 & 12.31 \\
\hline nAakkamudaiyar SG & $"$ & $"$ & & $"$ & 68 & 2.28 & 12 & 6.87 \\
\hline${ }^{\circ}$ Northern Eastern Ghats & --- & --- & $\begin{array}{l}17 \text { plots of } 0.1 \text { ha randomly } \\
\text { selected }\end{array}$ & $\geq 10$ & 135 & 5.2 & 266 & 8.65 \\
\hline${ }^{\circ}$ Southern Eastern Ghats & --- & --- & $\begin{array}{l}47 \text { plots of } 0.1 \text { ha randomly } \\
\text { selected }\end{array}$ & $"$ & 365 & 6.2 & 334 & 11.1 \\
\hline
\end{tabular}

Explanations: * - current study area, a - Rajarathinam (1990), b - Visalakshi (1995), c - King (1997), d - Parthasarathy \& Sethi (1997), e - Parthasarathy \& Karthikeyan (1997), f - Ramanujam \& Kadamaban (2001), g - Venkateswaran \& Parthasarathy (2003), h - Mani \& Parthasarathy (2006), i - Mani \& Parthasarathy (2009), j - Pandian \& Parthasarathy (2013), k - Anbarashan \& Parthasarathy (2012), 1 - Anbarashan \& Parthasarathy (2013), m - Baithalu et al. (2013), n - Sundarapandian \& Subbiah (2015), o - Babar et al. (2011) (except the current study area and Babar et al. (2011), all other studies have been carried out along the Coromandel coast of southern India - Tamil Nadu and Pondicherry), MAT - mean annual temperature, MAR - mean annual rainfall, S species richness, $\mathrm{H}$ - Shannon diversity index, $\mathrm{RF}$ - reserve forest, $\mathrm{SG}$ - sacred groves, $\mathrm{RD}$ - relatively undisturbed, $\mathrm{LD}$ - least disturbed, $\mathrm{MD}$ - moderately disturbed, MU - mostly disturbed, $\mathrm{HD}$ - highly disturbed, BA - basal area

type, the floristic elements differ based on the regional eco-climatic conditions. Currently, there is a need for a system of research that exclusively works on providing in-depth insights about richness, diversity and other floristic elements that can show a clear picture of forest under study, together with its current condition. This will help to analyze and comprehend the relationship between diversity parameters in relation to environmental conditions and, further, for conservation implications that may be the set goal of a study.

\subsection{Diversity patterns of other dry evergreen forests of southern India - status of KRF}

In view of above discussion, in the current study, we did not compare our results with any other forest types. However, we made an attempt to show diversity parameters of only dry evergreen forests (similar type) exclusively restricted to southern India, which has, to a certain extent analogous climate and environmental factors (Table 3). Compared to other forest types, dry evergreen forests are least studied within the country. They are found as scattered and patchy structures of the southern India, particularly towards the eastern coast, Tamil Nadu (Meher-Homji 1974; Parthasarathy et al. 2008).

As shown in Table 3, there are several discrepancies when comparing diversity and species richness between different dry evergreen forests, such as: (1) temperature and precipitation among sites ranged between 28.5 to $40{ }^{\circ} \mathrm{C}$ and 1033 to $2043 \mathrm{~mm}$; (2) the sampled area and its segmentation for inventory varied - most researchers adopted a contiguous plot of diverse dimensions, except Babar et al. (2011) and the current study. In comparison to contiguous sampling, a random quadrat survey conducted in heterogeneous areas captures good species richness (Prasad et al. 2007). This also has an impact on the species diversity, stem density $\left(\mathrm{ha}^{-1}\right)$ and basal area $\left(\mathrm{m}^{2} \mathrm{ha}^{-1}\right) ;(3)$ in most of the studies, there were sampled trees with $\mathrm{DBH} \geq 10 \mathrm{~cm}$, while in few with $\mathrm{DBH} \geq 20$ and $\geq 30 \mathrm{~cm}$; (4) only few studies have been carried out in disturbed forests; (5) in the study of Babar et al. (2011), $\log _{2}$ was used for diversity calculation, hence, their values are high compared to other studies that used natural logarithm.

Based on these variations, it is not appropriate to compare results and conclude that an area's diversity is low to one study and high to another study. For example, if species richness is considered, out of 41 case studies shown in Table 3, KRF richness is high compared to 31 sites, and low with respect to the rest of the sites, but there is variation in the area sampled, as well as the girth size considered during sampling. With respect to the number of stems $\mathrm{ha}^{-1}$, KRF stood third after the study sites 8 and 17 , and with reference to basal area $\left(\mathrm{m}^{2}\right.$ $h^{-1}$ ) was second after the site 32 , showing high values for both the parameters compared to the site 41 , where large area was sampled. The diversity values across sites cannot be compared due to variation in the log values used in different studies. There are a number of factors that actually influence the diversity parameters of an ecosystem and, thus, it is not appropriate to normalize the sites and compare. However, it is apt to compare diversity parameters of the same area at temporal intervals, like in the studies of Mani \& Parthasarathy (2009), Baithalu et al. (2013) and Pandian \& Parthasarathy (2016). In these studies, they showed the differences in species richness, diversity, and other parameters at an interval of 10 years. Such type of studies helps in assessing the species recruitment, loss, succession and other ecological processes concurrent with human pressure and in proposing future conservative measurements.

\section{Conclusions}

The KRF, a tropical dry evergreen forest of southern India, is one of the remnant forest patches in the vicinity 
of Vijayawada city that is prone to severe anthropogenic disturbances. The current study is first of a kind for the KRF with respect to species diversity analysis. This study provides baseline data about floristic structure and diversity of KRF for future temporal analysis and, further, for the reserve protection and conservation measurements. The study also argues not to compare diverse forest ecosystems with respect to their species richness and diversity patterns. It is suggested that researchers should come out of traditional way of comparing dissimilar ecosystems and should design a new approach of describing and understanding diversity of forest ecosystems.

Acknowledgements. Authors are thankful to University Grants Commission, New Delhi for funding this research work. The authors express gratitude to Mr Rajagopal for his help in field data collection and to the forest department for their support during field work. Thanks to anonymous reviewers for their critical comments in revising the manuscript.

\section{Author Contributions}

Research concept and design: Rama Chandra Prasad Acquisition and/or assembly of data: Rama Chandra Prasad, Asha Kumari

Data analysis and interpretation: Rama Chandra Prasad Drafting the article: Rama Chandra Prasad Critical revision: Rama Chandra Prasad, Asha Kumari Final approval: Rama Chandra Prasad, Asha Kumari Other: Asha Kumari (Principal Investigator), Rama Chandra Prasad (Co-Principal Investigator)

\section{References}

Allison S. D \& Vitousek P. M. 2004. Rapid nutrient cycling in leaf litter from invasive plants in Hawai'i. Oecologia 141: 612-619.

Amissah L., Mohren G. M. J., Bongers F., Hawthorne W. D. \& POORTER L. 2014 Rainfall and temperature affect tree species distribution in Ghana. J Trop Ecol 30: 435-446.

Anbarashan M. \& Parthasarathy N. 2012. Tree diversity and forest stand structure along disturbance gradients in Indian tropical dry evergreen forest. Ecotropica 18: 119-136.

Anbarashan M. \& Parthasarathy N. 2013. Tree diversity of tropical dry evergreen forests dominated by single or mixed species on the Coromandel Coast of India. Trop Ecol 54: 179-190.

Anonymous. 2001. Forest Report of Krishna District, Andhra Pradesh.

AnOnYmous. 2017. http://www.epw.in/journal/2017/25-26/ web-exclusives/amaravati-threatens-march-kondapalli.html

Armesto J. J., Mitchell J. D. \& Villagran C. 1986. A comparison of spatial patterns of trees in some tropical and temperate forests. Biotropica 18: 1-11.

Babar S., Giriraj A., Reddy C. S., Jurasinski G., Jentsch A. \& Sudhakar S. 2011. Spatial patterns of phytodiversity - assessing vegetation using (Dis) similarity measures, The dynamical processes of biodiversity - Case studies of evolution and spatial distribution, PhD. Oscar Grillo (Ed.), InTech, DOI: 10.5772/25075.

Baithalu M. S., Anbarashan M. \& Parthasarathy N. 2013 Two - decadal changes in forest structure and tree diversity in a tropical dry evergreen forest on the Coromandel Coast of India. Trop Ecol 54(3): 397-403.

Bellard C., Leclerc C. \& Courchamp F. 2014 Impact of sea level rise on the 10 insular biodiversity hotspots Glob. Ecol Biogeogr 23: 203-212.
Buzas M.A. \& HayeK L. A. C. 2005. On richness and evenness within and between communities. Paleobiology 31(2): 199-220.

Caswell H. 1976. Community structure: a neutral model analysis. Ecological Monographs 46: 327-354.

Cazzolla Gatti R., Castaldi S., Lindsell J. A., Coomes D. A., Marchetti M., Maesano M., Di Paola A., Paparella F. \& Valentini R. 2015. The impact of selective logging and clearcutting on forest structure, tree diversity and above-ground biomass of African tropical forests. Ecol Res 30(1): 119-132.

Champion H. G. \& Seth S. K. 1968. A revised survey of the forest types of India. Govt. of India Press.

Снао A. 1987. Estimating the population-size for capturerecapture data with unequal catchability. Biometrics 43: 783-91.

Colwell R. K. 2004. EstimateS: Statistical estimation of species richness and shared species from samples. Version 7. User's Guide and application published at: http:// purl.oclc.org/estimates. Department of Ecology \& Evolutionary Biology, University of Connecticut, Storrs.

Colwell R. K. 2009. Biodiversity: concepts, patterns and measurement. In: S. A. Levin (ed.) The Princeton guide to ecology, pp. 257-263. NJ, Princeton University Press, Princeton.

Cottam C. \& Curtis J. T. 1956. The use of distance measures in phytosociological sampling. Ecology 37(3) 451-460.

De Benedictis P. A. 1973. On the correlations between certain diversity indices. Am Nat 107: 295-302.

Denslow J. S 1995. Disturbance and diversity in tropical rain forests: the density effect. Ecol Appl 5: 962-968.

Denslow J. S. \& Hughes R. F. 2004. Exotic plants as ecosystem dominants. Weed Technol 18: 1283-1287.

Diggle P. 1983. Statistical analysis of spatial point patterns. Academic Press, London 
DonATo D. C. 2013. Limits to upward movement of subalpine forests in a warming climate. PNAS 110(20): 79717972. doi:10.1073/pnas.1305505110.

Heltshe J. \& Forrester N. E. 1983. Estimating species richness using the jackknife procedure. Biometrics 39: 1-11.

Hitimana J., KiYiapi J. L. \& NJunge J. T. 2004. Forest structure characteristics in disturbed and undisturbed sites of Mt. Elgon moist lower montane forest, western Kenya. Forest Ecol Manag 194: 269-291.

https:/en.climate-data.org/location/715084/ - climate data org accessed on $2^{\text {nd }}$ September 2017

Huang W., Pohjonen V., Johasson S., Nashanda M., Katigula Mil. \& LuUkKanen O. 2003. Species diversity, forest structure and species composition in Tanzanian tropical forests. Forest Ecol Manag 173:111-124.

Hurlbert S. H. 1990. Spatial distribution of the montane unicorn. Oikos 58: 257-271.

Iftekhar M. S \& Hoque A. K. F. 2005. Causes of forest encroachment: An analysis of Bangladesh. GeoJournal 62(1-2): 95-106.

KING O. 1997. Botanical and socio-cultural studies on sacred groves in Cuddalore District, Tamil Nadu, MPhil Dissertation, University of Madras. Department of Botany, Madras Christian College, Chennai, India.

Kotz S., Johnson N. L. \& Read C. B. (eds.). 1982-1988. Encyclopedia of Statistical Sciences, 9 vols. John Wiley \& Sons, Inc., New York.

Kumari Asha J., Rama Chandra Prasad P. \& Reddy K. B. 2010. Competitive exclusion of Parthenium hysterophorus by other invasive Species - A case study from Andhra Pradesh, India. Taiwania - International Journal of Life Sciences 55(2): 128-138.

Leelanandam 1994. The Kondapalli Layered Complex, Andhra Pradesh, India: geology, mineralogy and chemistry, pp. 517-518. Goldschmidt Conference Edinburgh 1994.

LePS Jan. \& KindLMAnN P. 1987. Models of the development of spatial pattern of an even-aged plant population over time. Ecol Model 39: 45-57.

Magurran A. E. 2004. Measuring Biological Diversity. Blackwell, Oxford.

Mani S. \& Parthasarathy N. 2006. Tree diversity and stand structure in inland and coastal troical dry evergreen forests of peninsular India. Current Science 90: 12381246.

Mani S. \& Parthasarathy N. 2009. Tree population and above-ground biomass changes in two disturbed tropical dry evergreen forests of peninsular India. Trop Ecol 50 249-258.

MARChese C. 2015. Biodiversity hotspots: A shortcut for a more complicated concept. Global Ecology and Conservation 3: 297-309.

Mener-Homs V. M. 1974. On the origin of the tropical dry evergreen forest of south India. International Journal of Ecology and Environmental Sciences 1: 19-39.

Mori S. A, Boom B. M, Carvalho A. M. \& Dos Santos T. S. 1983. Ecological importance of Myrtaceae in an eastern Brazilian moist forest. Biotropica 15: 68-69.
Odum E. P. 1971. Fundamentals of ecology (3rd ed.). W. B. Saunders and Co, Philadelphia, PA.

Padalia H., Chauhan N., Porwal M. C \& Roy P. S. 2004. Phytosociological observations on tree species diversity of Andaman Islands, India. Current Science 87(6): 799-806.

Pandian E. \& Parthasarathy N. 2016. Tree diversity changes over a decade (2003-2013) in four inland tropical dry evergreen forest sites of peninsular India. Journal of Forest and Environmental Sciences 32(2): 219-235.

Parthasarathy N. \& Karthikeyan R. 1997. Plant biodiversity inventory and conservation of two tropical dry evergreen forests on the Coromandel coast, of south India. Biodiver Conserv 6: 1063-1083.

Parthasarathy N., Selwyn M. A. \& Udayakumar M. 2008. Tropical dry evergreen forests of peninsular India: ecology and conservation significance. Trop Conserv Sci 1: 89-110.

Parthasarathy N. \& Sethi P. 1997. Tree and liana species diversity and population structure in a tropical dry evergreen forest in south India. Trop Ecol 38: 19-30.

Pech S. \& Sunada K. 2008. Population Growth And NaturalResources Pressures In The Mekong River Basin. Ambio 37(3): 219-24.

Pielou E. C. 1975. The measurement of diversity in different types of biological collections. J Theor Biol 13: 131144.

Prasad R. C. P., Reddy C. S. \& Dutt C. B. S. 2007. Phytodiversity assessment of tropical rainforest of North Andaman Islands, India. Research Journal of Forestry 1(1): 27-39.

Prasad R. C. P., Rajan K. S., Dutt C. B. S. \& Roy P. S. 2010. A conceptual framework to analyse the Land-use / land-cover changes and its impact on phytodiversity - A case study of North Andaman Islands, India. Biodiver Conserv 19(11) 3073-3087.

Prasad R.C.P., Rajan K.S. \& Asha Kumari J. 2011. Endangered forest ecosystem of Eastern Ghats - need for conservation of Kondapalli forest. IUP Journal of Life Sciences 5(4): 40-45.

Prasad R. C. P. \& Rajan K. S. 2014. Is current forest landscape research approaches providing the right insights? - Observations from Indian context? Ecological Questions 20: 85-92.

Primack R. B. \& Hall P. 1992. Biodiversity and forest change in Malaysian Borneo. Bio Sci 42: 829-837.

Pullaiah T \& Sandhya Rani S. 1999. Trees of Andhra Pradesh. Published by Regency Publications, 480 pp. 20/36-G, Old market, West Patel Nagar, New Delhi.

Pullaiah T. \& Sri Ramamurthy K. 2001. Flora of Eastern Ghats, hill Ranges of South East India.

Pullaiah T. \& Rao D. M. 2002. Flora of Eastern Ghats: Hill ranges of south east India. Vol. 1. Regency Publications, New Delhi.

RAJARATHINAM R. 1990. Habitat Evaluation of The Guindy National Park For Conservation Strategies Preliminary report for the period May-October 1990. Madras naturalists' society 1990 . 
Ramanujam M. P. \& KadAmban D. 2001. Plant biodiversity of two tropical dry ever green forests in the Pondicherry region of South India and the role of belief system in their conservation. Biodivers Conserv 10: 1203-1217.

Ramirez-Marcial N., Gonzalez-Espinosa M \& WilliamsLiNERA G. 2001. Anthropogenic disturbance and tree diversity in montane rain forests in Chiapas, Mexico. Forest Ecol Manag 154: 311-326.

Rao P., Barik S. K., Pandey H. N. \& Tripathi R. S. 1990. Community composition and tree population structure in a subtropical broadleaved forest along a disturbance gradient. Vegetatio 88: 151-162.

Rao Muralidhar A. \& Pullaiah T. 2007. Ethnobotanical Studies on Some Rare and Endemic Floristic Elements of Eastern Ghats-Hill Ranges of South East Asia, India. Ethnobotanical Leaflets 11: 52-70.

Raunkiaer C. 1934. The life forms of plants and statistical geography. Clarendon Press, Oxford.

Reddy C. S., Murthy M. S. R. \& Dutt C. B. S. 2001. Vegetational Diversity and Endemism in Eastern Ghats, India. Proceedings of National Seminar on Conservation of Eastern Ghats, pp. 109-134.

Reddy K. N., Madhuri V., Subbaraju G. V. \& Hemadri K. 2005. Ethnotherapeutics of certain Ayurvedic medicinal plants of Kondapalli fort, Andhra Pradesh. Indian Forester 131(3): 442-448.

Reddy K. N., Trimurthulu G. T. \& Reddy C. S. 2010. Plants used by the ethnic people of Krishna district, Andhra Pradesh. Indian Journal of Traditional Knowledge 9(2): 313-317.

Reshi Z., Khuroo A. A. \& Dar G. H. 2009. Plant species diversity in the Kashmir Himalayan grasslands along an elevational gradient. International Journal Ecology and Environmental Sciences 35(1): 91-100.

RichaRDS P. W. 1996. The tropical rainforest: an ecologic al study. United Kingdom, Cambridge University Press, Cambridge.

Salghuna N. N., Rama Chandra Prasad P. \& Asha Kumari J. 2018. Assessing the Impact of Land use and Land cover changes on the remnant patches of Kondapalli reserve forest of the Eastern Ghats, Andhra Pradesh, India. Egyptian Journal of Remote Sensing and Space Sciences, https://doi.org/10.1016/j.ejrs.2018.01.005

Sandhyarani S. K., Sri Rama Murthy \& Pullaiah T. 2007. Tree Flora in Eastern Ghats of Southern Peninsular India. Research Journal of Botany 2: 176-185.

Selby B. 1965. The index of dispersion as a test statistic. Biometrika 52: 627-629.
Seidler T. G. \& Plotkin J. B. 2006. Seed Dispersal and Spatial Pattern in Tropical Trees. PLoS Biol 4(11): e344. https://doi.org/10.1371/journal.pbio.0040344

Shruthakeerthiraja. \& Krishnakumar G. 2012. Phytosociological studies on a low altitude forest of the Western Ghats region - India. Indian Journal of Science 1(1): 64-70.

Shannon C., Wiener W. 1963. The Mathematical Theory of Communication. University of Illinois Press, Urbana, USA.

Simpson E. H. 1949. Measurement of diversity. Nature 163: 688.

Smith E. P. \& Van Belle G. 1984. Non-parametric estimation of species richness. Biometrics 40: 119-129.

Smiet A. C. 1992. Forest ecology on Java: human impact and vegetation of montane forest. J Trop Ecol 8: 129-152.

Stirling G. \& Wilsey B. 2001. Empirical relationship between Species richness, Evenness and proportional diversity. Am Nat 158: 286-299.

Stuart A. \& ORD J. K. 1991. Kendall's Advanced Theory of Statistics, Vol. 2. Oxford University Press, New York.

Sundarapandian S. M \& Subbiah S. 2015. Diversity and tree population structure of tropical dry evergreen forests in Sivagangai district of Tamil Nadu, India. Tropical Plant Research. 2(1): 36-46.

Timah E. A., Ajaga N., Tita D. F., Ntonga L. M. \& BongSIYSI I. B. 2008. Demographic pressure and natural resources conservation. Ecol Econ 64: 475-483.

VenKanna P. 1990. Medicinal plant wealth of Krishna district (Andhra Pradesh), a preliminary survey. Ancient Science Life 10: 137-140.

Venkateswaran R. \& Parthasarathy N. 2003. Tropical dry evergreen forests on the Coromandel coast of India: Structure, composition and human disturbance. Ecotropica 9: 45-58.

Visalakshi N. 1995. Vegetation analysis of two tropical evergreen forests in Southern India. Trop Ecol 36: 117-127.

Wisheu I. C. \& Keddy P. A. 1992. Competition and Centrifugal Organization of Plant Communities: Theory and Tests. J Veg Sci 3: 147-156.

Yi L.-T., Han H.-R ., Cheng X.-Q., Kang Fengfeng. \& Zhang Z.-J. 2008. Spatial distribution patterns of Quercus liaotungensis population in Lingkong Mountains. Shengtai Xuebao. Acta Ecologica Sinica 28: 32543261. 